\title{
Possible effect of the Tibetan Plateau on the "upstream" climate over West Asia, North Africa, South Europe and the North Atlantic
}

\author{
Mengmeng $\mathrm{Lu}^{1} \cdot$ Song Yang ${ }^{1,2,3} \cdot$ Zhenning $\mathrm{Li}^{1} \cdot \mathrm{Bian} \mathrm{He}^{4} \cdot \mathrm{Shan}_{\mathrm{He}^{1}} \cdot \mathrm{Ziqian}_{\text {Wang }}{ }^{1,2}$
}

Received: 23 July 2017 / Accepted: 9 October 2017 / Published online: 24 October 2017

(c) The Author(s) 2017. This article is an open access publication

\begin{abstract}
We conduct several experiments using a fullycoupled climate model to understand the role of Tibetan Plateau (TP) surface heating in the climate variations over West Asia, South Europe, North Africa, and the North Atlantic during summer. Emphasis has been placed on the physical processes and responsible mechanisms that involve the shift of the Hadley cell and the important features of rotational and divergent response of the atmosphere to the TP heating. The relative importance of the TP to the Asian continent is also analyzed. A heating of the TP surface leads to local increases in tropospheric temperature and the thickness of the air column due to the so-called air pumping effect. In the upper troposphere, the South Asian high intensifies and extends westward. To the west of TP, especially in West Asia, South Europe, North Africa, and the North Atlantic, distinguished Rossby wave responses to the TP heating occur with anomalous high pressure and uniform warming in the entire troposphere. Correspondingly, descending motions intensify and precipitation decreases. However, the tropical Sahel rainfall increases because of a northward shift of the Atlantic intertropical convergence zone and the anomalous
\end{abstract}

Song Yang

yangsong3@mail.sysu.edu.cn

1 School of Atmospheric Sciences, Sun Yat-sen University, 135 West Xingang Road, Guangzhou 510275, China

2 Guangdong Province Key Laboratory for Climate Change and Natural Disaster Studies, Sun Yat-sen University, Guangzhou, China

3 Institute of Earth Climate and Environment System, Sun Yat-sen University, Guangzhou, China

$4 \quad$ State Key Laboratory of Numerical Modeling for Atmospheric Sciences and Geophysical Fluid Dynamics, Institute of Atmospheric Physics, Chinese Academy of Sciences, Beijing, China westerlies due to the weakening of the southeastern portion of the Atlantic subtropical high. These effects of the TP heating explain a remarkable portion of the effects by the Asian continent heating. In addition, the impacts of different magnitudes of TP surface heating are also discussed.

Keywords Tibetan plateau $\cdot$ Heating and response . Atmospheric teleconnection $\cdot$ Climate variations

\section{Introduction}

Both observational analyses and model simulations have demonstrated that the Tibetan Plateau (TP) influences regional and global climate through dynamical and thermodynamical effects (Hahn and Manabe 1975; Ye and Wu 1998; Kitoh 2004; Liu et al. 2007; Wu et al. 2007, 2014; Bao et al. 2010). The TP acts as a large heat source in boreal summer (Jiang et al. 2016) and plays an important role in determining the structure of summer atmospheric circulation (Flohn 1957; Yeh et al. 1957). Ye and Wu (1998) pointed out that the low-level convergence and upper-level divergence induced by TP thermal forcing strongly influenced global climate through changes in meridional and zonal circulations and surface energy dispersion. Since the TP is positioned over the eastern Eurasian continent, the pattern of atmospheric circulation forced by TP is in phase with that induced by Eurasian continent forcing, and thus the strongest monsoon and largest deserts occur over the African-Eurasian continents (Wu et al. 2007, 2009).

Understanding of the impact of TP on regional and global climate has been enhanced by applying both atmospheric general circulation models and coupled atmosphere-ocean general circulation models. Hahn and Manabe (1975) suggested that the TP orography facilitated the South Asian 
monsoon to extend farther north to northern India through a comparison of model experiments with and without mountains. Abe et al. (2013) investigated the effect of TP on the onset of South Asian monsoon by modulating the air-sea interaction in the Indian Ocean. Also from a perspective of air-sea coupling, Kitoh (2004) found that the Baiu rainfall intensified and extended to Asian inlands with increasing mountain uplift. While the above studies have demonstrated the effects of TP orography including both mechanical forcing and thermal forcing, other studies have emphasized the impact of the dominant thermal forcing of the TP compared to its dynamical effect (Duan et al. 2008; Wu et al. 2012a, b; Rajagopalan and Molnar 2013), especially the effect of surface sensible heating (Wu et al. 1997, 2007, 2014; Wang et al. 2014; Duan et al. 2017; Liu et al. 2017). In particular, an air pumping effect driven by surface sensible heating over the TP was proposed (Wu et al. 1997, 2007). Among this context, Duan et al. (2017) suggested that the surface sensible heating over TP influenced the interannual variation of the western Pacific subtropical high. The interaction between surface sensible heating and latent heating over the TP was also illustrated by Wu et al. (2016), who found that the variations of atmospheric circulation induced by TP sensible heating were stronger than those forced by latent heating. Liu et al. (2017) further investigated the interaction between the sensible heating over the TP and that over the Iranian Plateau, with an emphasis on the mutual effect and offset effect of the two plateaus.

On interdecadal time scales, the June-July-August (JJA) mean surface temperature over the TP has increased significantly in the past decades (Fig. 1). Figure 1 shows that the surface air temperature averaged over the TP where topography over $23^{\circ} \mathrm{N}-45^{\circ} \mathrm{N} / 62^{\circ} \mathrm{E}-105^{\circ} \mathrm{E}$ is above $1500 \mathrm{~m}$ is $0.24{ }^{\circ} \mathrm{C}$ per decade, an important feature similar to that displayed by Duan and Xiao (2015). In the spatial pattern of the differences in surface and tropospheric temperatures between 2007-2016 and 1979-1988 (figure not shown), most apparent warming appears over South Europe, the TP, and East Asia, in both the surface and the troposphere.

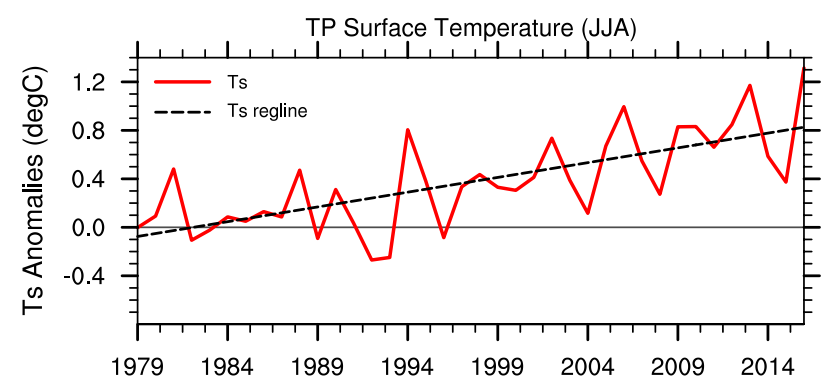

Fig. 1 Time series of JJA-averaged surface temperature over the TP during 1979-2016 (red curve, units: ${ }^{\circ} \mathrm{C}$ ) and its linear trend (black curve). The grey line indicates zero line
Moreover, an amplified warming trend over the TP has occurred since post-1990s compared to the so-called "global warming hiatus" (Duan and Xiao 2015, Su et al. 2017). Wang et al. (2008) suggested that the heating induced by increasing surface temperature over the TP could enhance East Asian summer rainfall, implying that rising TP temperature in the near future may result in further strengthened summer rainfall over East Asia.

By far, most of the studies on TP's climate effect have been focused on the impacts of TP heating on the climate in South, East, and Southeast Asia, but much less effort has been devoted to investigating the effects of TP on the climate in its "upstream" regions, which are referred to as West Asia, the Middle East, South Europe, North Africa, and the North Atlantic. It has been illustrated that the North African deserts and the Mediterranean climate are closely linked to the Asian summer monsoon heating through the east-west vertical circulation maintained by the longitudinal thermal contrast between the monsoon and desert regions (Yang et al. 1992) and also through the Rossby waves induced by the monsoon heating (Rodwell and Hoskins 1996, 2001). Zhao et al. (2012) have also demonstrated that the Asian continent surface heating leads to interannual variations of atmospheric circulation and sea surface temperature over the North Atlantic and western Eurasian continent. Enhanced heat transfer from the land surface to the atmosphere over Asia leads to an increased local tropospheric temperature and westward-propagating positive temperature anomalies from Asia to the North Atlantic, causing rising tropospheric temperatures over Eurasia and the Atlantic. Accordingly, positive pressure anomalies and anticyclonic circulation anomalies occur over the extratropical North Atlantic. However, the role of TP surface heating in the effect of Asian land on the upstream climate in the previous studies has not been fully explained.

In this study, we use a state-of-the-art earth system model to understand the effects of TP surface heating on the summer climate of the "upstream" regions (West Asia, the Middle East, South Europe, North Africa, and the North Atlantic), with an emphasis on the physical processes and the responsible mechanisms that involve the variations of both the rotational and the divergent responses of atmospheric circulation. The relative importance of the TP heating to the Asian continent heating is also investigated.

This paper is organized as follows. In Sect. 2, the data sets and model used in the study are described. The details of model experiment design are also introduced. In Sect. 3, the effects of Asian surface heating on the atmospheric circulation and surface climate in the "upstream" regions are illustrated. The effects of TP surface heating and their associated physical processes and responsible mechanisms are investigated in Sect. 4. Finally, conclusions and a further discussion are given in Sect. 5. 


\section{Data, model and experiment design}

\subsection{Data}

Surface air temperature anomalies are obtained from the Goddard Institute for Space Studies (GISS/NASA) surface temperature analysis (Hansen et al. 2010), which are provided by the NOAA/OAR/ESRL PSD, Boulder, Colorado, USA, from the website at http://www.esrl.noaa.gov/ psd/. Atmospheric fields are from the European Centre for Medium-range Weather Forecasts (ECMWF) reanalysis i.e. the ERA-Interim Reanalysis (Dee et al. 2011). We also use the precipitation data from the NASA/GSFC Global Precipitation Climatology Project (GPCP) Version 2.3 (Adler et al. 2003), which is from the NOAA/OAR/ESRL PSD, Boulder, Colorado, USA, at the website http://www.esrl. noaa.gov/psd/.

\subsection{Model}

The model used in this study is the Community Earth System Model version 1.2.2 (CESM 1.2.2) from the National Center for Atmospheric Research (NCAR), which is a fullycoupled global climate model that can provide state-of-theart simulations of climate states and be used for plenty of scientific research (Neale et al. 2013). We conduct a series of fully-coupled experiments to investigate the effects of TP surface heating and Asian continent heating on the variations of climate in "upstream" regions. The atmospheric resolution is $1.9^{\circ}$ in latitude and $2.5^{\circ}$ in longitude with 26 vertical levels, and the oceanic resolution is approximately $1^{\circ}$. The values are fixed at the level of year 2000 for following variables: solar forcing, ozone concentration, carbon dioxide, and aerosol.

\subsection{Experiment design}

Model experiment design is briefly described in Table 1. Our experiments are fully-coupled simulations, and $\mathrm{CON}$ is the control run (a free run) that is integrated for 300 years and the output for years 261-300 is analyzed. Previous studies have demonstrated that land processes are important for changes in regional and global climate (Yeh et al. 1984; Barnett et al. 1989; Yang and Lau 1998; Wu et al. 2012a, b; Si and Ding 2013) and the albedo effect can influence surface temperature and then modulate the Asian summer monsoon through altering land-sea thermal contrast (Barnett et al. 1989). It should be pointed out that understanding the impact of surface thermal condition on atmospheric circulation through modification of surface albedo has been a common practice in numerous previous studies (e.g. Wang et al. 2008; Boos and Kuang 2010; Liu et al. 2012). When surface albedo decreases, land surface absorbs more solar radiation and surface temperature increases accordingly, and vice versa. Thus, in our sensitive experiments we decrease land surface albedo from May to September in an Asian domain and the TP to heat the Asian continent and the plateau, respectively.

To understand the effect of Asian surface heating on climate, we perform a sensitive experiment "Asia_Alb0.5" that is restarted from year 251 of $\mathrm{CON}$ and the integration period is from year 251 to year 300 , in which external forcing is the same as in CON but surface albedo in Asia $\left(25^{\circ}-50^{\circ} \mathrm{N}\right.$, $60^{\circ} \mathrm{E}-120^{\circ} \mathrm{E}$ ) is reduced with multiplying by 0.5 . Experiment TP_Alb0.5 is the same as Asia_Alb0.5 but surface albedo is decreased in the TP region where the topography over $23^{\circ} \mathrm{N}-45^{\circ} \mathrm{N} / 62^{\circ} \mathrm{E}-105^{\circ} \mathrm{E}$ is higher than $1500 \mathrm{~m}$. To investigate the impacts of different magnitudes of TP surface heating, we conduct experiments TP_Alb0.8 and TP_Alb0, in which TP surface albedo is multiplied by 0.8 and 0 , respectively. All outputs of sensitive experiments are analyzed for years 261-300.

The JJA climatological patterns of surface temperature, tropospheric temperature, precipitation, and 850$\mathrm{hPa}$ winds in observations and the CON run are shown in Fig. 2. The model can well capture the distributions of surface temperature and tropospheric temperature obtained from the ERA-Interim Reanalysis, although the magnitude of surface temperature is slightly overestimated (Fig. 2a, b). Moreover, compared to observations, the tropospheric warm center over South Asia in CON is somehow too strong and is located slightly too westward.

Table 1 Model experiment design

\begin{tabular}{ll}
\hline Experiments & Configurations \\
\hline CON & External forcing at the level of year 2000,300 years integrated \\
Asia_Alb0.5 & Branch run from CON year 251 restarts fields, with decreased surface albedo (multiplied by \\
& $0.5)$ in Asian region $\left(25^{\circ}-50^{\circ} \mathrm{N}, 60^{\circ} \mathrm{E}-120^{\circ} \mathrm{E}\right)$ \\
TP_Alb0.5 & Same as Asia_Alb0.5, but with decreased surface albedo in TP region, where the topography \\
& in $23^{\circ} \mathrm{N}-45^{\circ} \mathrm{N}, 62^{\circ} \mathrm{E}-105^{\circ} \mathrm{E}$ is higher than $1500 \mathrm{~m}$ \\
TP_Alb0.8 & Same as TP_Alb0.5, but with lightly decreased surface albedo (multiplied by 0.8$)$ in TP region \\
TP_Alb0 & Same as TP_Alb0.5, but with no surface albedo (multiplied by 0$)$ in TP region
\end{tabular}




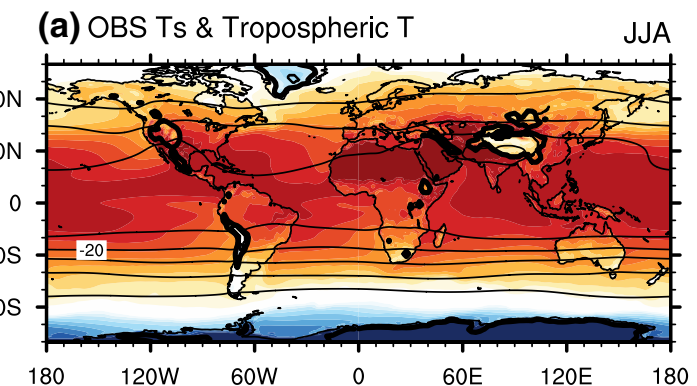

(c) OBS Precip \& UV850

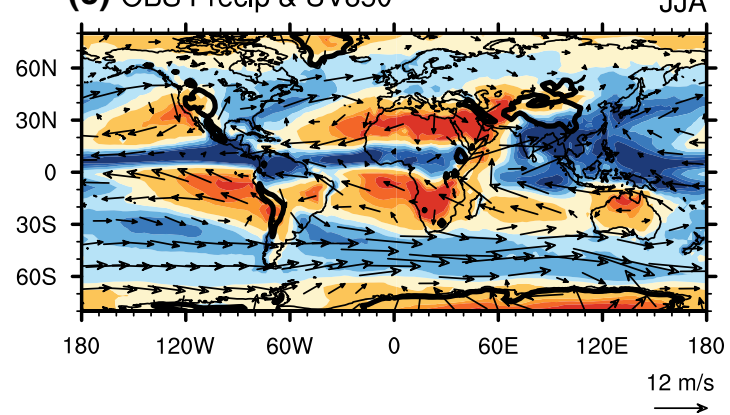

Fig. 2 Observed climatology of a JJA surface temperature (shadings, units: ${ }^{\circ} \mathrm{C}$ ) and tropospheric temperature (contours, units: ${ }^{\circ} \mathrm{C}$ ) and c JJA precipitation (shadings, units: $\mathrm{mm} \mathrm{day}^{-1}$ ) and $850-\mathrm{hPa}$ winds (vectors, units: $\mathrm{m} \mathrm{s}^{-1}$ ) for the period of 1979-2016. b Same as $\mathbf{a}$ but for CON run, and $\mathbf{d}$ same as $\mathbf{c}$ but for CON run. The topography higher than $1500 \mathrm{~m}$ is marked with thick black lines. Tropospheric

The mid-Atlantic trough also extends too westward. The distribution of precipitation is also well reproduced by CON, although the precipitation over North Africa and the east of Japan is slightly underestimated and the Asian monsoon rainfall is overestimated (Fig. 2c, d). In observation (Fig. 2c), the rainfall over the northwestern TP is less than that over the southeastern TP, and the model certainly captures this feature in spite of an overestimation over the southeastern TP. The excellent performance of the model in simulating the distribution and magnitude of $850 \mathrm{hPa}$ winds also demonstrates that the NCAR CESM is suitable for our investigations on the climate effect of TP surface heating.

Figure $3 \mathrm{a}, \mathrm{b}$ respectively show the domains of Asia Alb0.5 and TP experiments including TP_Alb0.5, TP Alb0.8, and TP_Alb0. Figure 3c presents the difference in JJA surface temperature between Asia_Alb0.5 and CON and Fig. 3d shows the difference between TP_Alb0.5 and $\mathrm{CON}$, indicating the changes in surface temperature in Asia_Alb0.5 and TP_Alb0.5, respectively. The temperatures over most of the TP increase about $2.5^{\circ} \mathrm{C}$, and those over the northwestern TP increase above $3.5^{\circ} \mathrm{C}$. This value is larger than the warming trend shown in Fig. 1, and it is comparable with the magnitude of temperature increase presented by Wang et al. (2008, see their Fig. 1).

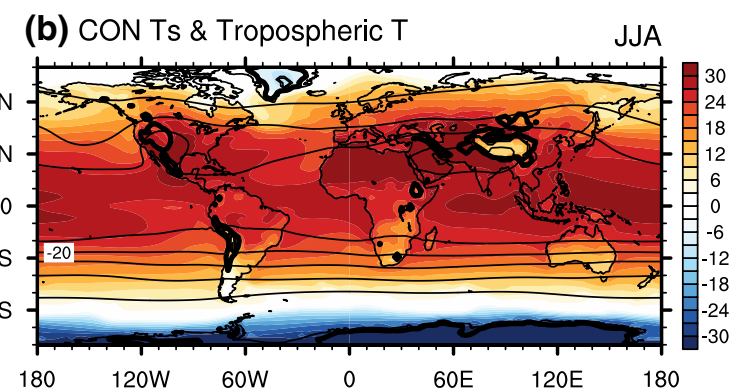

(d) CON Precip \& UV850

JJA

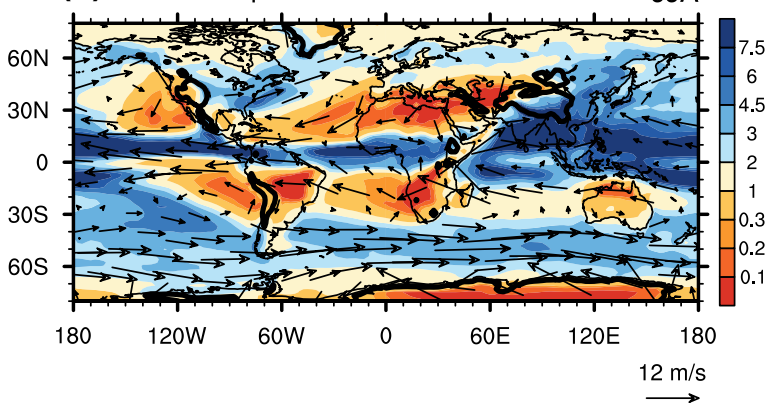

temperature in the region where topography is lower than $3000 \mathrm{~m}$ is calculated by vertical integration from 700 to $200 \mathrm{hPa}$, while it is calculated by vertical integration from 500 to $200 \mathrm{hPa}$ in the region higher than 3000 meters. Hereafter, the calculation of tropospheric temperature is all conducted in this way

\section{Effect of Asian continent heating}

In this section, we illustrate the effect of Asian surface heating on the variations of upstream climate. The analysis is expected to provide a reference for the discussion of the effect of TP surface heating (see next section), along with comparison with the relevant result of Zhao et al. (2012). Figure 4 depicts the JJA climatology of surface temperature, surface sensible heat flux, latent heat flux, and 500-hPa vertical velocity in $\mathrm{CON}$ and the corresponding differences in these fields between Asia_Alb0.5 and CON. Climatologically, maximum surface temperature occurs over the tropical Indian Ocean, the tropical western Pacific, subtropical deserts, and southern North America. Sensible heat flux is larger over land, especially in the western part of Eurasian continent, North Africa, and North America, than over oceans (Fig. 4c). Latent heat flux is larger over the tropics and subtropical oceans, compared with the subtropical arid regions and middle-high latitudes (Fig. 4e). The pattern of 500-hPa vertical velocity (Fig. $4 \mathrm{~g}$ ) well corresponds to that of precipitation (Fig. 2d), with strong descent over the eastern oceans and subtropical deserts and ascent over the tropics and monsoon regions.

In the Asia_Alb0.5 run, surface temperature increases significantly over nearly entire Asia, northeastern Africa, 

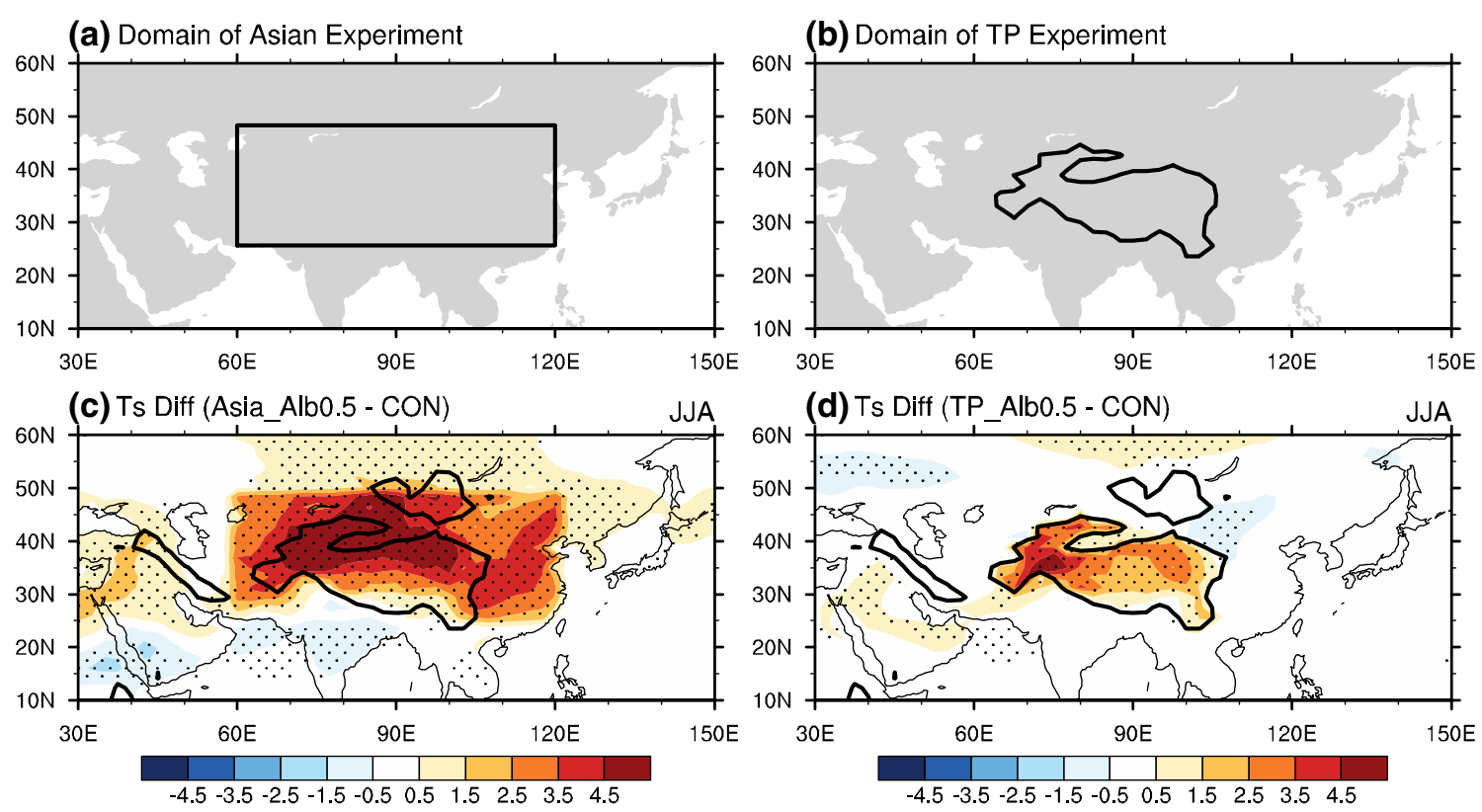

Fig. 3 a Domain of Asia_Alb0.5 $\left(25^{\circ}-50^{\circ} \mathrm{N}, \quad 60^{\circ} \mathrm{E}-120^{\circ} \mathrm{E}\right)$. b Domain of TP experiments (TP_Alb0.5, TP_Alb0.8, and TP_Alb0) where the topography in $23^{\circ} \mathrm{N}-45^{\circ} \mathrm{N}, 62^{\circ} \mathrm{E}-105^{\circ} \mathrm{E}$ is higher than $1500 \mathrm{~m}$. c Difference in JJA surface temperature (units: ${ }^{\circ} \mathrm{C}$ ) between

Asia_Alb0.5 run and CON run. d Same as c, but for the difference between TP_Alb0.5 run and CON run. The dots indicate the values that are significantly above the $95 \%$ confidence level. In $\mathbf{c}$ and $\mathbf{d}$, the topography higher than $1500 \mathrm{~m}$ is marked with thick black lines

South Europe, the extratropical North Atlantic, and North America but decreases over India, tropical-subtropical Africa, and the subtropical North Atlantic (Fig. 4b). Corresponding to the increased surface temperature, sensible heat flux is enhanced over Asia, South Europe, and North Africa (Fig. 4d). Similarly, weakened sensible heat appears over India and tropical Africa. It is evident that the latent heat flux (Fig. 4f) over land co-varies with the change in 500-hPa vertical velocity (Fig. 4h) that reflects precipitation variation. The soil is wetter when there is more precipitation, increasing surface latent heat flux. As a result, latent heat flux increases over the TP, East Asia, and tropical Africa, and decreases over the regions to the west. Anomalous rising motion occurs over the TP and to its east (Fig. 4h) due to the enhanced sensible heating. Strengthened descent forms over South Europe, the Mediterranean Sea, and the extratropical North Atlantic, which is linked to the intensified ascent over the regions to the east. The pattern of difference in 500-hPa vertical velocity shown in Fig. $4 \mathrm{~h}$ is similar to that presented by Rodwell and Hoskins (1996, their Fig. 8), which indicates a Rossby wave response to the strengthened diabatic heating in Asia induced by local surface heating. In addition, the ascent over Sahel is enhanced and the descent over the subtropical deserts and subtropical North Atlantic is weakened.

The JJA climatology of 500-hPa geopotential height, 850-hPa winds, tropospheric temperature, and 200-hPa winds in $\mathrm{CON}$ and the corresponding differences between Asia_Alb0.5 and CON are given in Fig. 5. In the lower

atmosphere, an anticyclonic circulation dominates over the subtropical North Atlantic, with a center around $30^{\circ} \mathrm{N}, 45^{\circ} \mathrm{W}$ (Fig. 5a), and a cyclonic circulation forms in the Asian monsoon region. To the south of the cyclonic system including India, the Bay of Bengal, and the Indo-China Peninsula, southwesterly wind prevails. To the east i.e. the East Asian monsoon region, southerly flow is dominant. In the middle troposphere, high pressure forms over the North Atlantic and northwestern Africa, and relatively low pressure appears in the other regions. In the upper troposphere, there exist two prominent atmospheric circulation systems: the South Asian High (SAH) and the mid-Atlantic trough (Fig. 5c). An anomalous low-level cyclonic circulation appears over Asia when surface temperature increases (Fig. 5b). In the meanwhile, a huge anomalous anticyclonic circulation forms to the west, indicating an intensified and northward shifted Atlantic subtropical high (ASH). Anticyclonic anomalies in the upper troposphere are also found over the subtropical and mid-latitude Afro-Eurasia, indicating that the SAH intensifies and extends westward (Fig. 5d). In the Asian monsoon region, the low-level cyclonic circulation and the upper-level anticyclonic circulation consist of a baroclinic structure. However, in the regions to the west, anomalous anticyclonic circulations dominate in the entire troposphere, indicating a quasi-barotropic structure. Correspondingly, tropospheric temperature co-varies with the anomalous anticyclonic circulations, showing a uniform warming in the atmosphere. Moreover, the features of temperature and atmospheric 

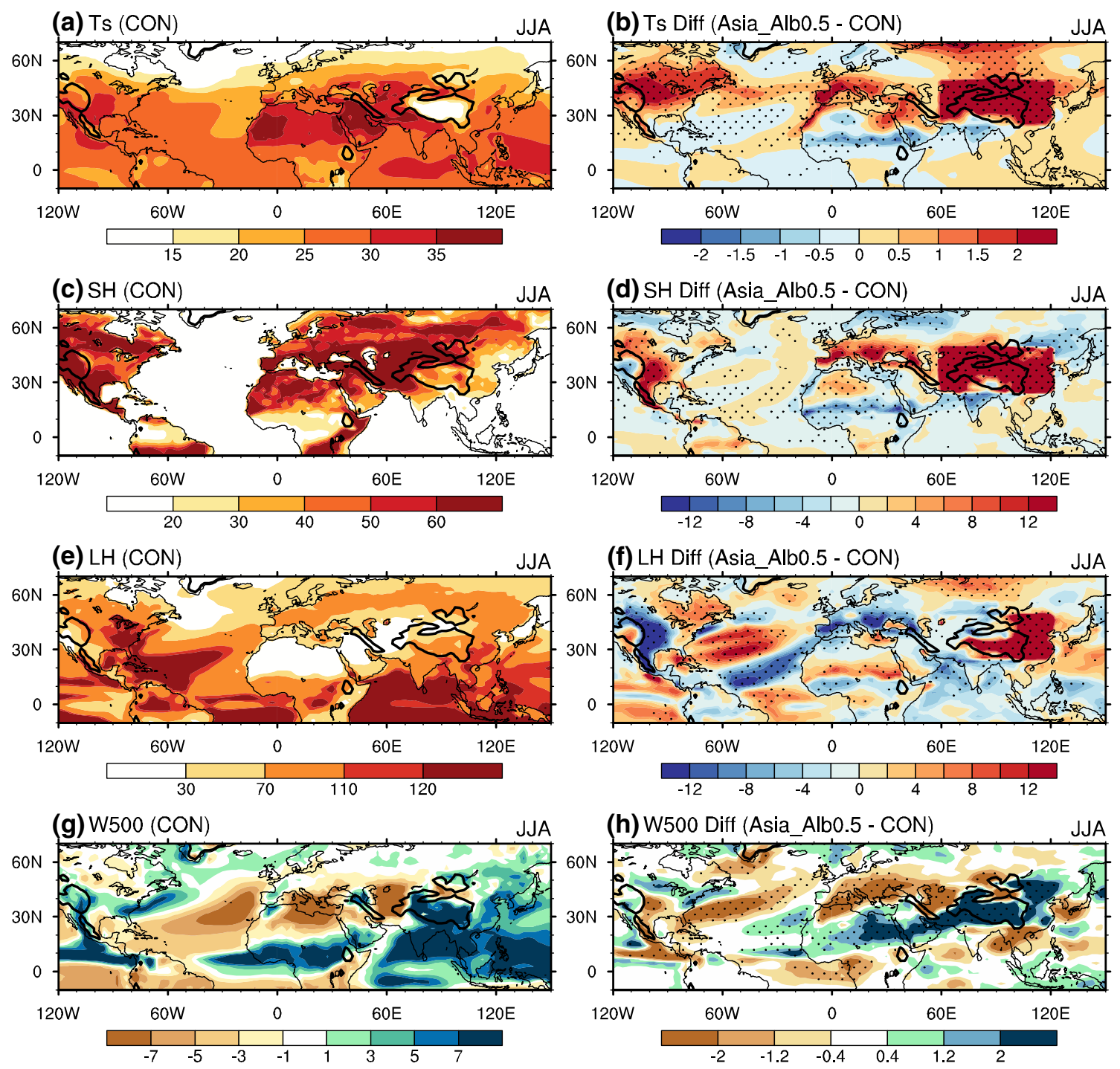

Fig. 4 JJA Climatology of a surface temperature (units: ${ }^{\circ} \mathrm{C}$ ), $\mathbf{c}$ surface sensible heat flux (units: $\mathrm{W} \mathrm{m}^{-2}$ ), e latent heat flux (units: $\mathrm{W} \mathrm{m}^{-2}$ ), and $\mathbf{g} 500-\mathrm{hPa}$ vertical velocity (units: $\mathrm{Pa} \mathrm{s}^{-1}$ ) in CON. Differences in $\mathbf{b}$ surface temperature (units: ${ }^{\circ} \mathrm{C}$ ), $\mathbf{d}$ surface sensible heat flux (units: $\mathrm{W} \mathrm{m}^{-2}$ ), f latent heat flux (units: $\mathrm{W} \mathrm{m}^{-2}$ ), and $\mathbf{h} 500-\mathrm{hPa}$

circulation over the Asian continent and the North Atlantic in experiment Asia_Alb0.5 are similar to those presented by Zhao et al. (2012), with increased surface and tropospheric temperatures and anomalous high pressure in the upper troposphere over Asia and the North Atlantic.

\section{Effect of TP surface heating}

In this section, our main effort is devoted to investigating the role of TP surface heating in the variations of upstream climate during summer, with an emphasis on the physical processes and responsible mechanisms. We also discussed vertical velocity (multiplied by 200, units: $\mathrm{Pa} \mathrm{s}^{-1}$ ) between Asia Alb0.5 and CON. The dots indicate the values that are significantly above the $95 \%$ confidence level. The topography higher than $1500 \mathrm{~m}$ is marked with thick black lines

the relative importance of the TP heating to the Asian continent heating illustrated in the above section.

\subsection{Variations of surface heat fluxes, atmospheric circulation and surface climate}

Figures 6 and 7 show the changes in surface temperature, surface heat fluxes, 500-hPa vertical velocity, and rainfall in TP_Alb0.5 during summer. In the TP_Alb0.5 run, surface temperature increases over the TP and its west, especially in South Europe, the Middle East, and the extratropical North Atlantic (Fig. 6a), and decreases over Sahara and the subtropical North Atlantic. Although the TP only 


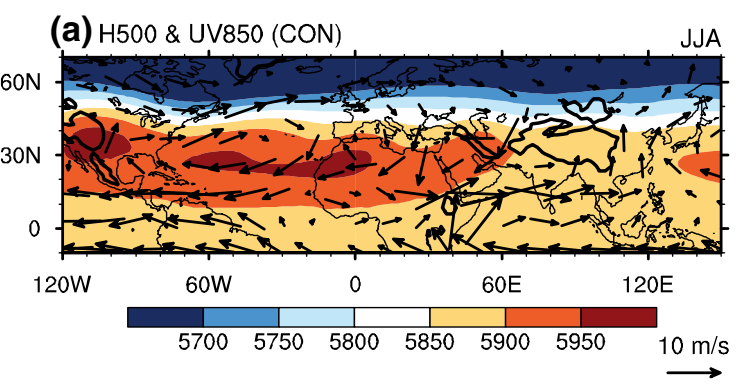

(c) Tropospheric T \& UV200 (CON)

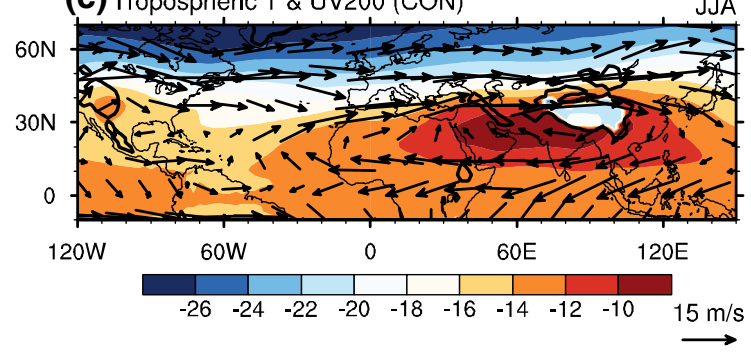

Fig. 5 JJA climatology of a 500-hPa geopotential height (shadings, units: $\mathrm{m}$ ) and $850-\mathrm{hPa}$ winds (vectors, units: $\mathrm{m} \mathrm{s}^{-1}$ ) and $\mathbf{c}$ tropospheric temperature (shadings, units: ${ }^{\circ} \mathrm{C}$ ) and $200-\mathrm{hPa}$ winds (vectors, units: $\mathrm{m} \mathrm{s}^{-1}$ ) in CON. b Differences in 500-hPa geopotential height (shadings, units: $\mathrm{m}$ ) and $850-\mathrm{hPa}$ winds (vectors, units: $\mathrm{m} \mathrm{s}^{-1}$ ) between Asia_Alb0.5 and CON. d Same as b, but for the differences

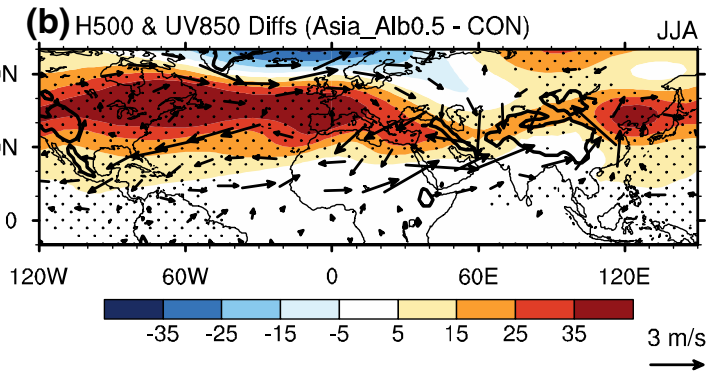

(d) Tropospheric T \& UV200 Diffs (Asia_Alb0.5 - CON) JJA

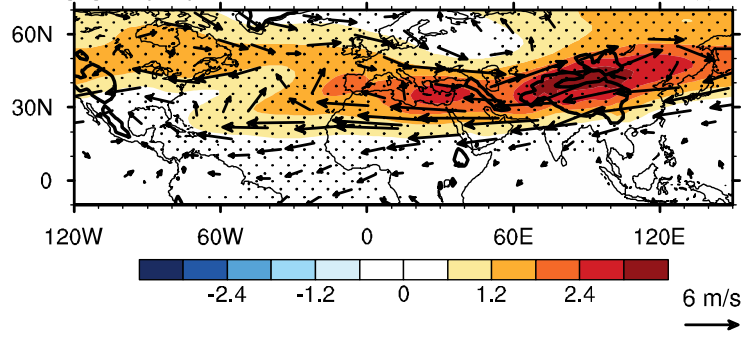

in tropospheric temperature (shadings, units: ${ }^{\circ} \mathrm{C}$ ) and $200-\mathrm{hPa}$ winds (vectors, units: $\mathrm{m} \mathrm{s}^{-1}$ ). The dots indicate the values that are significantly above the $95 \%$ confidence level. Only the values of differences in horizontal winds that are significantly above the $95 \%$ confidence level are plotted. The topography higher than $1500 \mathrm{~m}$ is marked with thick black lines (a) Ts Diff (TP_Alb0.5 - CON)
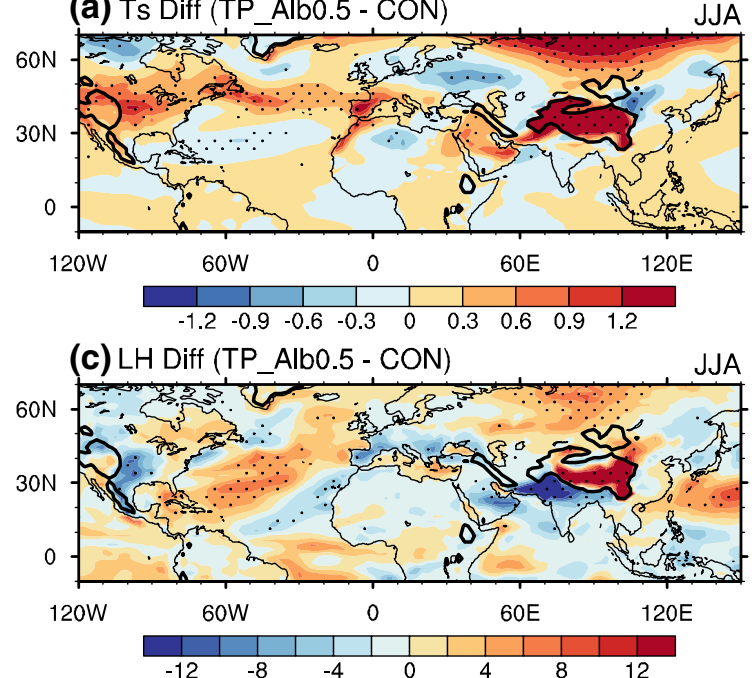

Fig. 6 JJA differences in a surface temperature (units: ${ }^{\circ} \mathrm{C}$ ), b surface sensible heat flux (units: $\mathrm{W} \mathrm{m}^{-2}$ ), $\mathbf{c}$ latent heat flux (units: $\mathrm{W} \mathrm{m}^{-2}$ ), and d 500-hPa vertical velocity (multiplied by 200, units: $\mathrm{Pa} \mathrm{s}^{-1}$ )

occupies one-third of the Asian domain in our experiments, the magnitude of increased surface temperature over the upstream regions in experiment TP_Alb0.5 is about 50\% of that in experiment Asia_Alb0.5, meaning that the TP forcing accounts for a large part of the climate effect of the Asian surface heating. The pattern of difference in sensible (b) SH Diff (TP_Alb0.5 - CON)
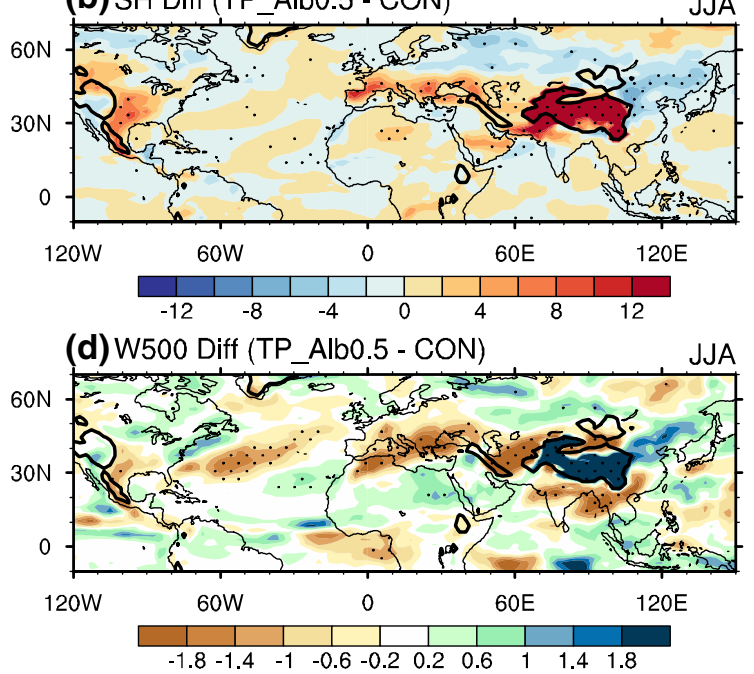

between TP_Alb0.5 and CON. The dots indicate the values that are significantly above the $95 \%$ confidence level. The topography higher than $1500 \mathrm{~m}$ is marked with thick black lines

heat flux is similar to that of Asia_Alb0.5 minus CON with enhanced sensible heating over the TP, South Europe, North Africa, and the southern Middle East (Fig. 6b). As seen from Fig. 6c, latent heat flux increases over nearly the entire TP and decreases over the west and the south, and the pattern is overall similar to that shown in Fig. $4 \mathrm{f}$ except for the changes 


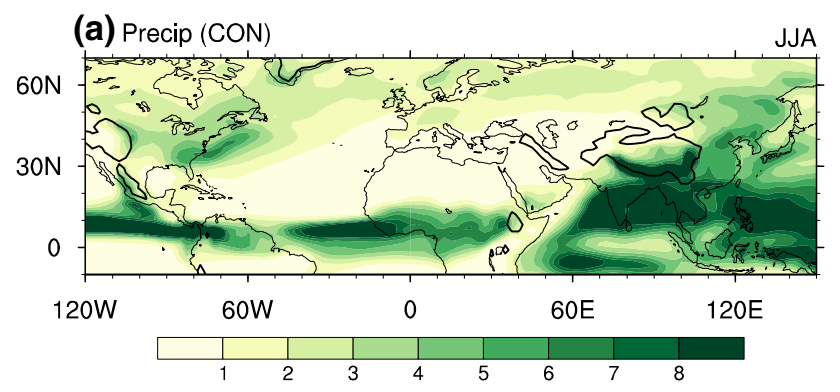

(b) Precip Diff (TP_Alb0.5 - CON)

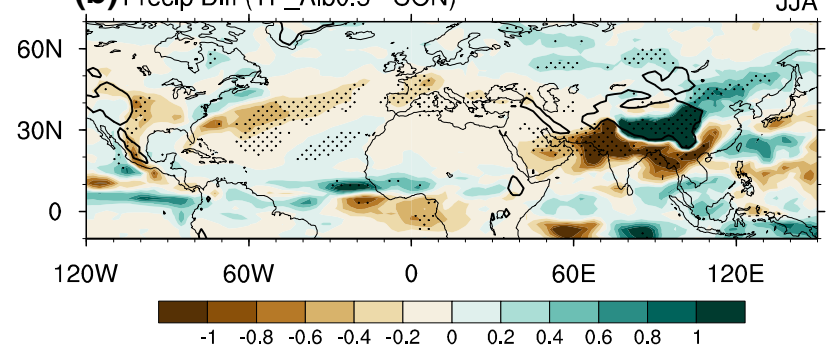

Fig. 7 a Climatology of JJA precipitation (units: $\mathrm{mm} \mathrm{day}^{-1}$ ) in CON, and $\mathbf{b}$ corresponding difference between TP_Alb0.5 and CON. The dots indicate the values that are significantly above the $95 \%$ confidence level. The topography higher than $1500 \mathrm{~m}$ is highlighted with thick black lines

over East Asia. Driven by the strengthened surface sensible heating, intensified rising motion (Fig. 6d) and rainfall (Fig. 7b) appear over the TP. Consequently, low-level flow converges toward the TP and climbs up along the mountain slope. These features are consistent with those of the "air pump" demonstrated by Wu et al. (1997, 2007), who referred to the process as the TP sensible heat driving air pump (TPSHAP). In the theory of Wu et al. (2007), the large-scale convergence can be reinforced by the latent heating over the TP. Thus, there exists a positive feedback between the effect of TP-SHAP and small-scale convective activity. The ascent and rainfall over East Asia are also enhanced due to the important TP thermal forcing (Wu et al. 2007, 2012; Wang et al. 2008). However, an interesting and important feature to note is that intensified descending motions and reduced rainfall occur in the regions to the west of TP i.e. West Asia, the Middle East, the Mediterranean Sea, South Europe, and the extratropical North Atlantic. According to Rodwell and Hoskins (1996, 2001), we assume with confidence that these are the Rossby wave response to the strengthened diabatic heating over the TP. In addition, the ascent over Sahel is stronger than that in CON, accompanied by an increase in rainfall (Fig. 7b). However, the ascent over northern India is weakened, associated with a decrease in rainfall.

The JJA differences in atmospheric circulation and tropospheric temperature between TP_Alb0.5 and CON are presented in Fig. 8. The enhanced sensible heating over the TP intensifies low-level cyclonic circulation, and anomalous high pressure and anticyclonic circulation form over South

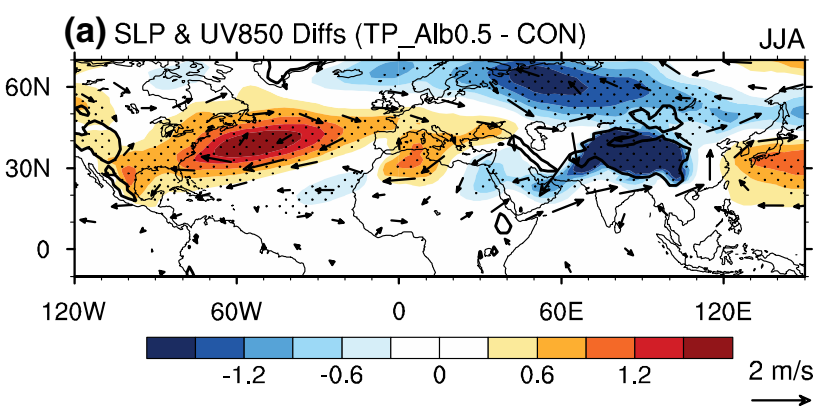

(b) H500 \& UV500 Diffs (TP_Alb0.5 - CON)

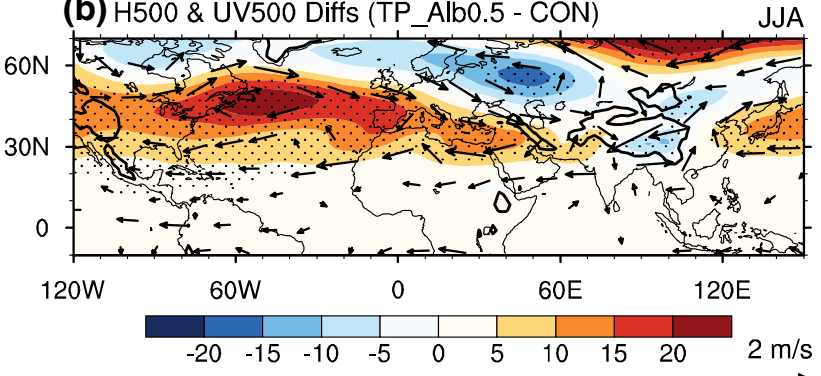

(c) Tropospheric T \& UV200 Diffs (TP_Alb0.5 - CON)

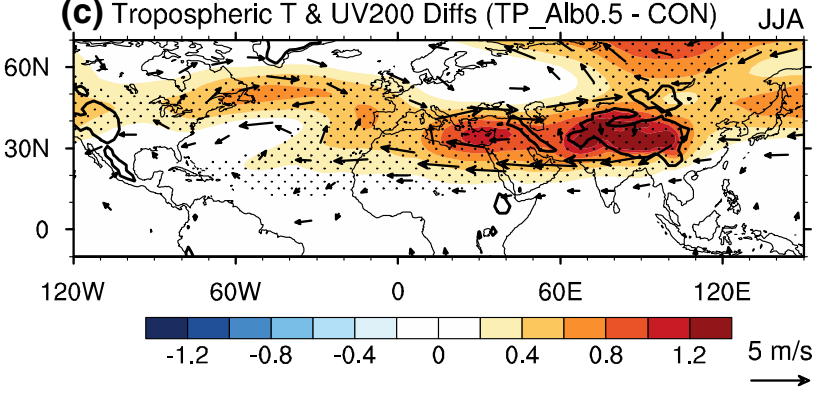

Fig. 8 Same as Fig. 6, but for a sea level pressure (shadings, units: $\mathrm{hPa}$ ) and 850-hPa winds (vectors, units: $\mathrm{m} \mathrm{s}^{-1}$ ), b 500-hPa geopotential height (shadings, units: $\mathrm{m}$ ) and 500-hPa winds (vectors, units: $\mathrm{m} \mathrm{s}^{-1}$ ), and $\mathbf{c}$ tropospheric temperature (shadings, units: ${ }^{\circ} \mathrm{C}$ ) and 200 $\mathrm{hPa}$ winds (vectors, units: $\mathrm{m} \mathrm{s}^{-1}$ ). The dots indicate the values that are significantly above the $95 \%$ confidence level. Only the values of differences in horizontal winds that are significantly above the 95\% confidence level are plotted. The topography higher than $1500 \mathrm{~m}$ is highlighted with thick black lines

Europe, North Africa, and the extratropical North Atlantic (Fig. 8a). Correspondingly, the ASH intensifies and its center moves northwestward to about $35^{\circ} \mathrm{N}, 50^{\circ} \mathrm{W}$. However, the southeastern part of ASH weakens with westerly anomalies to its south. These anomalous westerlies transport more water vapor from the tropical Atlantic to the Sahel, inducing more Sahel rainfall (Fig. 7b). The westerly anomalies to the south of the anomalous cyclonic circulation over the TP reduce the water vapor transported from the Bay of Bengal (Jiang and Ting 2017), leading to the decreased rainfall over northern India (consistent with the Fig. $4 \mathrm{f}$ in Wang et al. 2016 and the Fig. 3b in Wu et al. 2016). Our analysis reveals an anti-phase relationship between the northern Indian rainfall and the Sahel rainfall associated with the TP heating (Fig. 7b). This feature is similar to that shown by $\mathrm{He}$ 
et al. (2017), who recently demonstrated that the intensified heating in the South Asian monsoon region could lead to a decrease in Sahel rainfall, but demonstrates the important role of TP heating in the Asian-African climate link. Boos and Hurley (2013) also left a clue about the connection between Asian summer monsoon and North African deserts in a model experiment with truncated topography over the west of TP, in which the weakened heating over South Asia is accompanied by a positive anomaly of moist static energy over northern Africa.

The patterns of atmospheric circulation are similar between the lower troposphere and the middle troposphere, indicating a quasi-barotropic structure (Fig. 8b). In the upper troposphere, a huge anomalous anticyclonic circulation occurs over the subtropical and mid-latitude Afro-Eurasia and North Atlantic regions, with an intensified and westward extended SAH (Fig. 8c). It is clear that an apparent Rossby wave response to the TP diabatic heating occurs in the regions to the west of TP. Furthermore, a uniform warming of tropospheric temperature well corresponds to the upperlevel anomalous anticyclonic circulation. The magnitude of increased tropospheric temperature over the upstream regions in the TP_Alb0.5 run is about $40 \%$ of that in the Asia_Alb0.5 run, and the coefficient of pattern correlation between the two experiments (see Figs. 8c, 5d) is 0.93, indicating a large contribution of TP forcing to the Asian forcing in its climate effect. However, the signal of tropospheric temperature over North America in experiment TP_Alb0.5 is not as evident as that in experiment Asia_Alb0.5 (Fig. 5d).

Figure 9 shows the cross section of JJA differences in air temperature and diabatic heating between TP_Alb0.5 and CON. The temperature pattern indicates a uniform warming in the entire troposphere (Fig. 9a). A warm center appears over the TP and it then extends westward from the TP to the North Atlantic. In Fig. 9b, significant enhanced diabatic heating appears over the plateau but slight cooling occurs to the west, implying that the strengthened TP heating is a source of the Rossby wave pattern and it leads to a westward extension of high temperature.

\subsection{Variations of vertical circulation}

The TP is located in the subtropics, a transition zone between the tropics where the divergent part of the atmospheric circulation is important and the mid-latitudes where the rotational part is more dominant. Thus, both the thermally-driven circulation features and the Rossby wave train characteristics of the atmospheric response to TP thermal forcing should be investigated. Figure 10 shows the features of zonal-vertical cell along $30^{\circ}-40^{\circ} \mathrm{N}$ and meridional-vertical cell along $75^{\circ}-105^{\circ} \mathrm{E}$. Climatologically, strong rising motion occurs over the Asian monsoon region and sinking motion appears over the west (Fig. 10a). Two intensive ascending centers
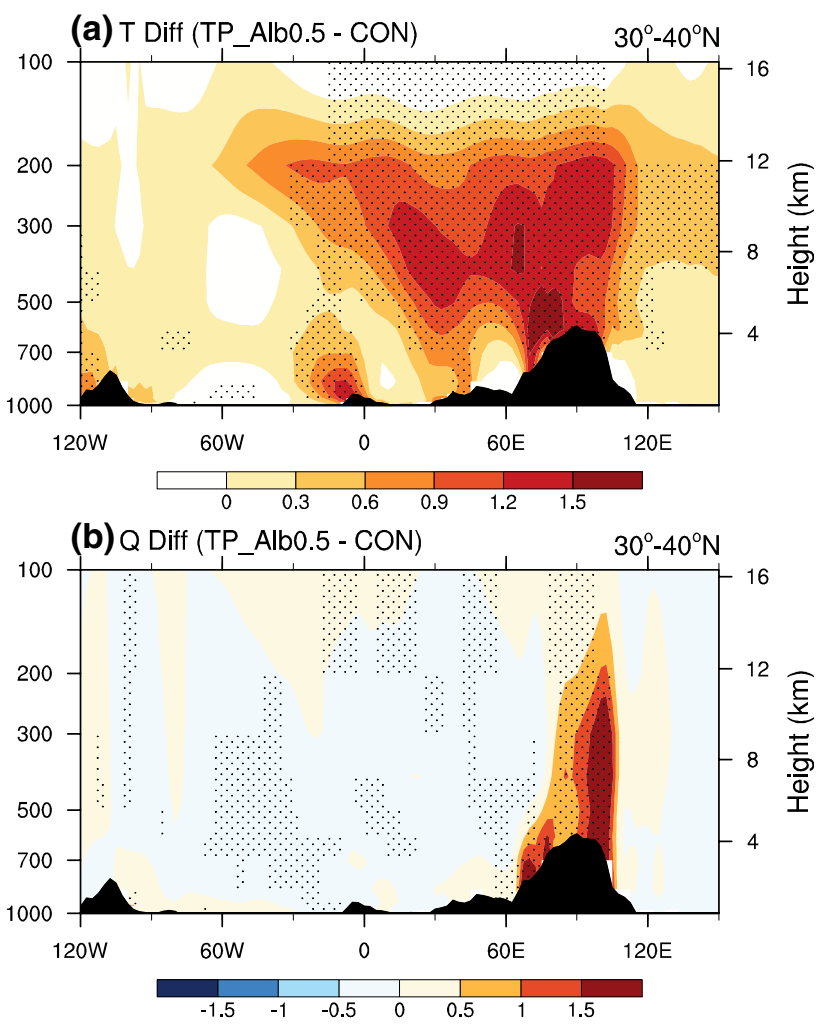

Fig. 9 a Cross section of the difference in $30^{\circ}-40^{\circ} \mathrm{N}$ mean JJA air temperature (units: ${ }^{\circ} \mathrm{C}$ ) between TP_Alb0.5 and CON. b Same as a, but for the difference in diabatic heating. The dots indicate the values that are significantly above the $95 \%$ confidence level

occur over the southern TP and to the south, respectively (Fig. 10c). When the TP heating is enhanced, the ascent over the TP and the descent to the west of TP strengthen correspondingly (Fig. 10b), leading to development of an anomalous warm center just between the ascent in the east and the descent in the west (Fig. 8c), in agreement with temperaturevertical heating gradient $\left(\mathrm{T}-\mathrm{Q}_{\mathrm{z}}\right)$ relationship demonstrated by Wu et al. (2015). The $T-Q_{z}$ theory starts from the following thermal wind relationship and the Sverdrup vorticity balance (also see Liu et al. 2001):

$\frac{\partial \phi}{\partial \ln p}=-R T$

$\frac{\partial v}{\partial \ln p}=-\frac{R}{f}\left(\frac{\partial T}{\partial x}\right)$

$\beta v \approx(f+\zeta) \theta_{z}^{-1}\left(\frac{\partial Q}{\partial z}\right), \theta_{z} \neq 0, \vec{V} \cdot \nabla \zeta \rightarrow 0$.

Then, the cause-and-effect relationship between vertical heating gradient and temperature distribution in the subtropics is derived (see detailed derivation in Wu et al. 2015): 


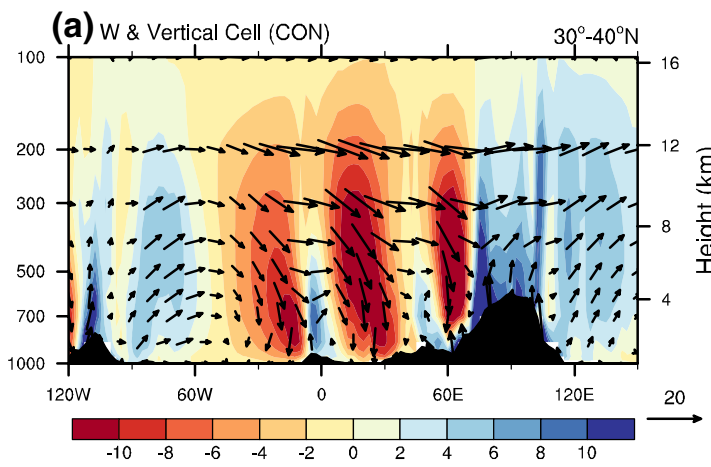

(c) $W$ \& Vertical Cell (CON)

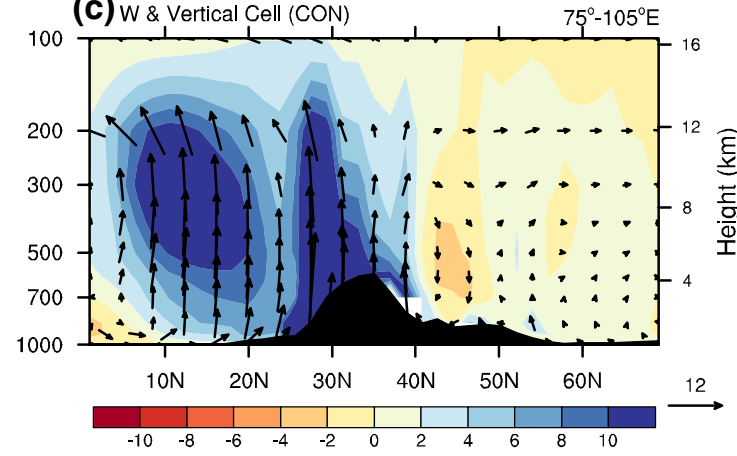

Fig. 10 a Climatology of $30^{\circ}-40^{\circ} \mathrm{N}$ averaged JJA vertical velocity (shadings, units: $\mathrm{Pa} \mathrm{s}^{-1}$ ) and vertical cell (vectors, $\mathrm{u}$ in $\mathrm{m} \mathrm{s}^{-1}$; vertical velocity is multiplied by 200 and is in $\mathrm{Pa} \mathrm{s}^{-1}$ ) in CON, and b corresponding differences between TP_Alb0.5 and CON. c Climatology of $75^{\circ}-105^{\circ} \mathrm{E}$ averaged JJA vertical velocity (shadings, units: $\mathrm{Pa} \mathrm{s}^{-1}$ ) and vertical cell (vectors, $\mathrm{v}$ in $\mathrm{m} \mathrm{s}^{-1}$; vertical velocity is multiplied

$T(x) \approx \gamma L^{2} H_{Q}{ }^{-2} \frac{\partial Q(x)}{\partial x}=\lambda \frac{\partial Q(x)}{\partial x}, \vec{V} \cdot \nabla \zeta \rightarrow 0 ;$

$\lambda=\gamma L^{2} H_{Q}{ }^{-2}$.

In the upper troposphere, deep convective heating $\left(\frac{\partial Q}{\partial Z}<0\right)$ and radiative cooling $\left(\frac{\partial Q}{\partial Z}>0\right)$ dominate.

According to Eq. (3), vertical northerly-wind shear exists in the heating region, while southerly-wind shear occurs in the cooling region. Then, according to Eq. (2), warming (cooling) center must appear in the region to the west (east) of heating and the region to the east (west) of cooling. Equation (4) means that temperature maximum/minimum leads to diabatic heating/cooling for a quarter of phase, that is, the temperature maximum is located between diabatic heating in the east and cooling in the west. Therefore, the zonal-vertical cell induced by the TP heating can contribute to the development of the descent in the west and the formation of a tropospheric warm center. In addition, it is evident that the pattern of vertical motion between $60^{\circ} \mathrm{W}$ and $120^{\circ} \mathrm{E}$ is enhanced in experiment TP_Alb0.5, meaning that the Rossby wave pattern as demonstrated by Rodwell and Hoskins (1996) intensifies. Thus, Fig. 10b features the result from the combined effect

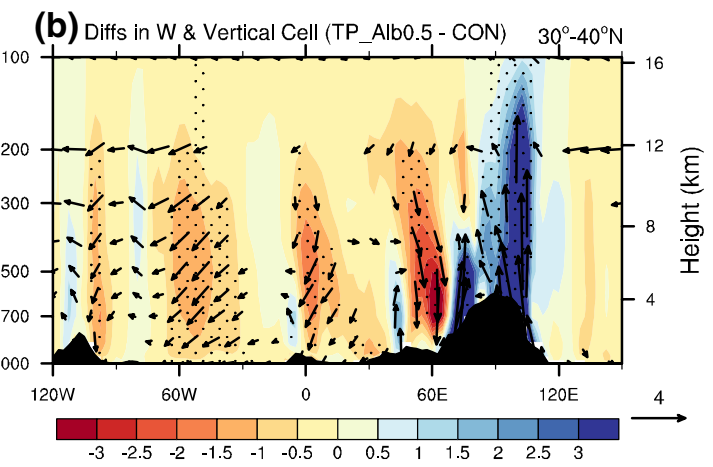

(d) Diffs in W \& Vertical Cell (TP_Alb0.5 - CON) $75^{\circ}-105^{\circ} \mathrm{E}$

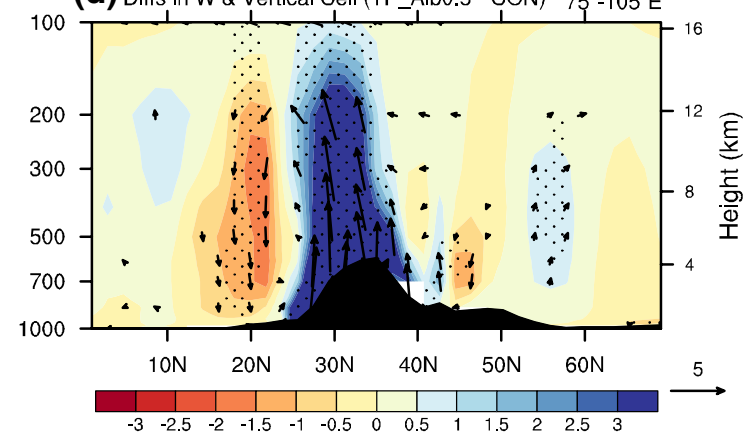

by 200 and is in $\mathrm{Pa} \mathrm{s}^{-1}$ ) in CON, and $\mathbf{d}$ corresponding differences between TP_Alb0.5 and CON. The dots indicate the values that are significantly above the $95 \%$ confidence level. In $\mathbf{b}$ and $\mathbf{d}$, only the values of differences in vertical cell that are significantly above the $95 \%$ confidence level are plotted

of the anomalous zonal-vertical cell and the intensified Rossby wave response to the TP diabatic heating. In Fig. 10d, an anomalous meridional-vertical cell forms with anomalous descent over northern India and ascent over the plateau, contributing to the decrease in northern Indian rainfall and the increase in TP rainfall.

As seen from the difference in rainfall between $\mathrm{TP}_{-}$ Alb0.5 and CON (Fig. 7b), an anomalous north-south dipole of rainfall appears over the tropical Atlantic and tropical western Africa, indicating a northward shift of the Atlantic intertropical convergence zone (ITCZ). A northward shift of ASH leads to decreases in trade wind and evaporation, resulting in an increase in local SST and the northward shift of the Atlantic ITCZ. Then, if the Atlantic ITCZ migrates northward, how does the local Hadley cell change? Fig. 11 shows the JJA meridional-vertical cell along $10^{\circ} \mathrm{W}-30^{\circ} \mathrm{E}$ and the corresponding difference. Climatologically, local Hadley circulation is presented clearly (Fig. 11a), with ascent over the tropics and descent over the subtropics. As seen from the corresponding difference (Fig. 11b), this Hadley circulation moves northward with an anomalous ascending branch around $20^{\circ} \mathrm{N}$ and an anomalous descending branch around $40^{\circ} \mathrm{N}$ when the TP heating is enhanced, inducing weakened descent 


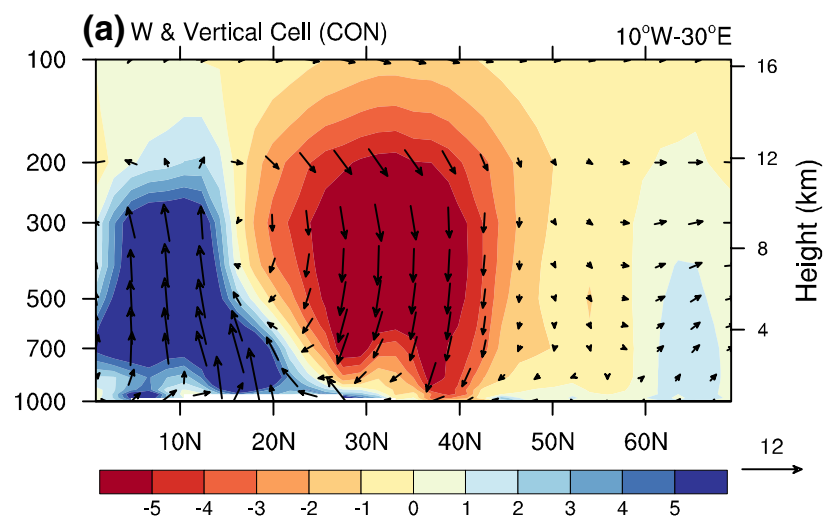

(b) Diffs in W \& Vertical Cell (TP_Alb0.5 - CON) $10^{\circ} \mathrm{W}-30^{\circ} \mathrm{E}$

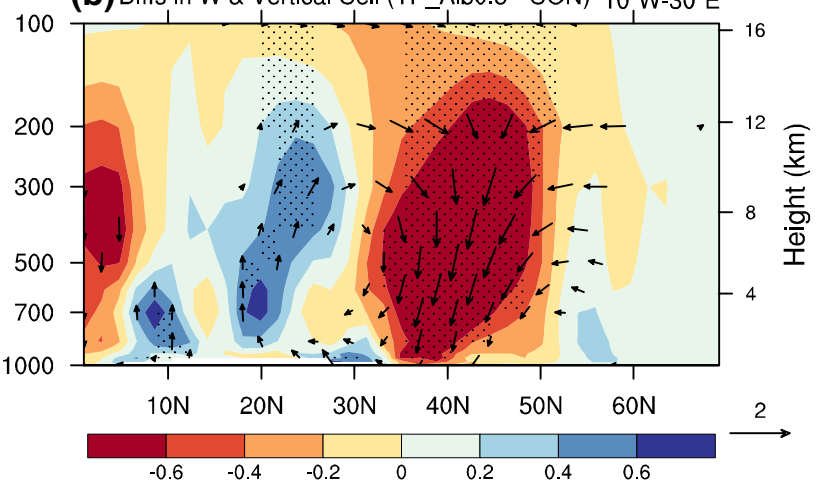

Fig. 11 a Climatology of $15^{\circ}-35^{\circ} \mathrm{E}$ averaged JJA vertical velocity (shadings, units: $\mathrm{Pa} \mathrm{s}^{-1}$ ) and vertical cell (vectors, $\mathrm{v}$ in $\mathrm{m} \mathrm{s}^{-1}$; vertical velocity is multiplied by 200 and is in $\mathrm{Pa} \mathrm{s}^{-1}$ ) in CON, and $\mathbf{b}$ corresponding differences between TP_Alb0.5 and CON. The dots indicate the values that are significantly above the $95 \%$ confidence level. In b, only the values of differences in vertical cell that are significantly above the $95 \%$ confidence level are plotted

over Sahara and strengthened descent over South Europe and the Mediterranean Sea region. That is, the northward shifted Hadley cell contributes to the drier climate over South Europe and the Mediterranean Sea region.

\subsection{Physical processes and mechanisms}

In short, the physical processes and mechanisms responsible for the effect of TP surface heating on the upstream climate can be summarized as follows. In the TP region, surface temperature increases when surface albedo decreases, which enhances sensible heating and rising motion. Anomalous convergence occurs at the low levels, and the upper-tropospheric SAH intensifies and extends westward. Meanwhile, condensational heating also intensifies, which further enhances the low-level convergence and the upward motion, generating a positive feedback between large-scale convergence and smaller-scale convective activity. In the regions to the west of TP, a Rossby wave response to the TP diabatic heating occurs, featured by anomalous anticyclonic circulation and warm tropospheric temperature in the entire troposphere. The anomalous tropospheric warm center and the anomalous zonal-vertical cell with the ascent (decent) in the east (west) are also in agreement with the $\mathrm{T}-\mathrm{Q}_{\mathrm{z}}$ relationship. In the lower atmosphere, the ASH strengthens and extends eastward, and its center moves northwestward, strengthening the descent over the extratropical North Atlantic. In the meantime, the Atlantic ITCZ and local Hadley circulation also shift northward, resulting in increased Sahel rainfall, weakened descent in the Sahara deserts, and enhanced descent in South Europe and the Mediterranean Sea region. However, the southeastern portion of ASH weakens, with anomalous westerlies over the tropical eastern Atlantic and the Sahel, which transport more water vapor from the North Atlantic to the Sahel and produce more rainfall. Finally, in the regions to the south especially over northern India, an anomalous meridional-vertical cell induced by the TP heating and low-level westerly anomalies to the south of the anomalous cyclonic circulation over the TP contribute to a decrease in northern Indian rainfall, and this decreased rainfall and the increased rainfall over Sahel are of the context of a climate link between Africa and Asia related to the thermal driving of monsoon heating (also see He et al. 2017).

\section{Conclusions and discussion}

In this study, we have conducted several experiments using an update fully-coupled climate model to understand the effect of TP surface heating on the variations of climate over West Asia, the Middle East, South Europe, North Africa, and the North Atlantic during summer, with an emphasis on the physical processes and responsible mechanisms. We have focused on the role of TP surface heating and depicted the detailed broad features of the changes in the atmospheric circulation over the TP region and particularly to its west, involving not only the patterns of Rossby wave response, but also the changes in the divergent circulation of thermally-driven nature (especially the local Hadley cell) and the Atlantic ITCZ. We have also discussed relative importance of the TP heating to Asian continent heating for affecting the upstream climate.

A heating of the TP surface leads to local increases in tropospheric temperature and the thickness of the air column due to the so-called air pumping effect. In the upper troposphere, the SAH intensifies and extends westward. In the regions to the west of TP especially in West Asia, South Europe, North Africa, and the North Atlantic, a distinct Rossby wave response occurs with the characteristics of anomalous anticyclonic circulation and atmospheric warming in the entire troposphere. Correspondingly, descending motion intensifies and precipitation decreases. The ASH and associated downward motion intensify and the center moves 


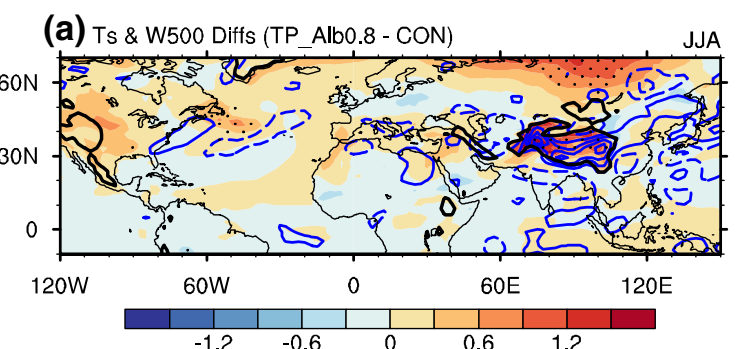

(c) Tropospheric T \& UV200 Diffs (TP_Alb0.8 - CON)

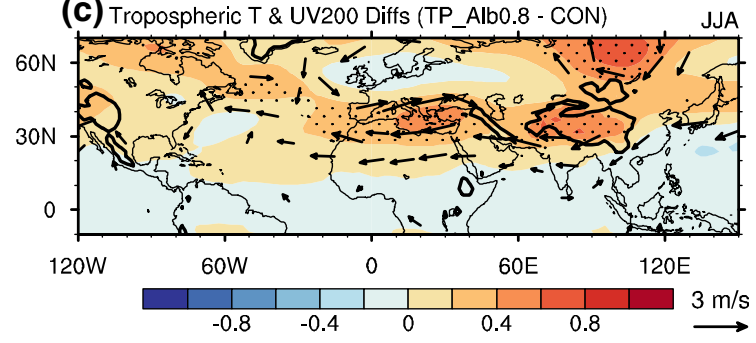

Fig. 12 JJA differences in a surface temperature (shadings, units: ${ }^{\circ} \mathrm{C}$ ) and $500-\mathrm{hPa}$ vertical velocity (multiplied by 200 , blue contours, units: $\mathrm{Pa} \mathrm{s}^{-1}$ ), and $\mathbf{c}$ tropospheric temperature (shadings, units: ${ }^{\circ} \mathrm{C}$ ) and 200-hPa winds (vectors, units: $\mathrm{m} \mathrm{s}^{-1}$ ) between TP_Alb0.8 and CON. $\mathbf{b}$ and $\mathbf{d}$ are respectively the same as a and $\mathbf{c}$, but for the dif-

northwestward, leading to the northward shifts of the Atlantic ITCZ and the local Hadley circulation. However, the thermally-driven circulation features is also distinguished. When the TP heating is enhanced, an anomalous zonal-vertical cell appears with ascending motion over the TP and descending motion over the Mediterranean Sea region. According to the $\mathrm{T}-\mathrm{Q}_{\mathrm{z}}$ relationship proposed by Wu et al. (2015), anomalous high pressure and uniform warming appear in the entire troposphere between the ascending motion over the TP and the descending motion over the regions to the west of TP. It turns out that the effects of Rossby wave response and anomalous zonal-vertical cell are nearly in phase. However, the tropical Sahel rainfall increases because of the northward shifts of the Atlantic ITCZ and the local Hadley cell and the anomalous westerlies due to the weakening of the southeastern portion of the ASH. The increase in Sahel rainfall is also associated with a decrease in the rainfall over northern India in the TP surface heating experiment.

The result of Asia_Alb0.5 experiment, which is consistent with that of Zhao et al. (2012) from a relatively lower version of the NCAR model, serves as a reference for understanding the relative climate effect of TP surface heating. It is found that the features of atmospheric circulation variations in the TP_Alb0.5 run are overall similar to those in the Asia_Alb0.5 run. Although the TP only occupies one-third of the Asian domain in our experiments and the increase in surface temperature in TP_Alb0.5 is also smaller than that in Asia_Alb0.5, the effect of TP heating explains a remarkable portion of the effect on upstream climate by the Asian continent heating. The magnitudes of increased surface and

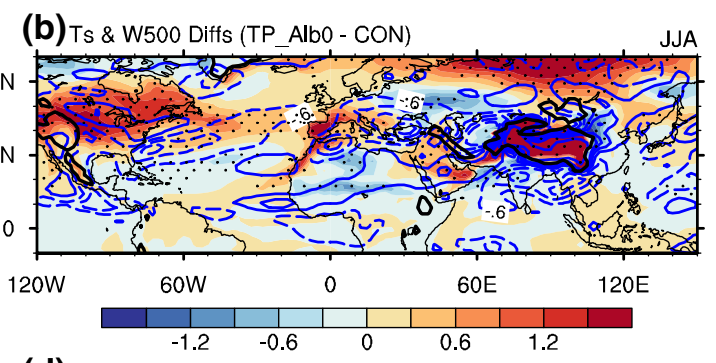

(d) Tropospheric T \& UV200 Diffs (TP_Albo - CON)

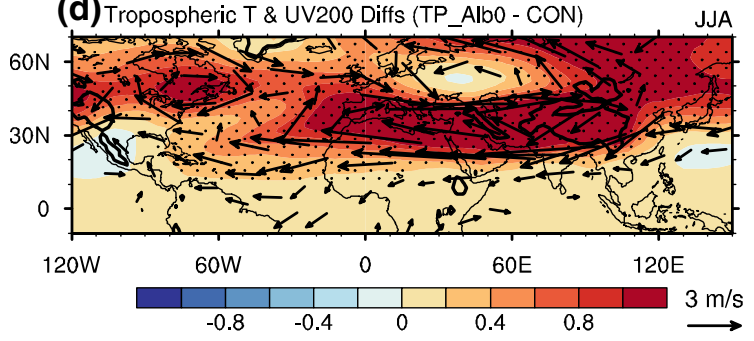

ferences between TP_Alb0 and CON. The dots indicate the values that are significantly above the $95 \%$ confidence level. Only the values of differences in $200-\mathrm{hPa}$ winds that are significantly above the $95 \%$ confidence level are plotted. The topography higher than $1500 \mathrm{~m}$ is marked with thick black lines

tropospheric temperatures over the upstream regions in experiment TP_Alb0.5 are about $40-50 \%$ of that in experiment Asia_Alb0.5.

We have also conducted two additional TP experiments: light heating run "TP_Alb0.8" and strong heating run "TP_Alb0", in which surface albedo over the TP is multiplied by 0.8 and 0 , respectively. The patterns of temperature and atmospheric circulation in these two experiments are shown as examples in Fig. 12. As surface heating over the TP is stronger, the magnitudes of atmospheric fields become significantly larger. However, only small changes can be found in the features of spatial distribution of the fields. These results from additional experiments indicate that the above-discussed features about the effect of TP surface heating on upstream climate revealed by our sensitive experiments are robust. However, the effects of Atlantic SST on the variations of TP and its upstream atmospheric circulation and the Atlantic ITCZ have not been investigated. A series of experiments using coupled and uncoupled climate models in addition to the experiments discussed in this study to address the related issue are being conducted.

Acknowledgements We thank the two anonymous reviewers for their valuable comments and constructive suggestions for improving the overall quality of this paper. We also appreciate the effective discussions with Prof. Wen Zhou of the City University of Hong Kong, Prof. Bohua Huang of the George Mason University, Prof. Eric Maloney of the Colorado State University, Prof. Wenhong Li of the Duke University, and Dr. Qing Bao of the Chinese Academy of Sciences. This study was supported by the National Natural Science Foundation of China 
(Grant 91637208), the National Key Scientific Research Plan of China (Grant 2014CB953904), the National Key Research and Development Program of China (2016YFA0602703), and the Jiangsu Collaborative Innovation Center for Climate Change.

Open Access This article is distributed under the terms of the Creative Commons Attribution 4.0 International License (http://creativecommons.org/licenses/by/4.0/), which permits unrestricted use, distribution, and reproduction in any medium, provided you give appropriate credit to the original author(s) and the source, provide a link to the Creative Commons license, and indicate if changes were made.

\section{References}

Abe M, Hori M, Yasunari T, Kitoh A (2013) Effects of the Tibetan Plateau on the onset of the summer monsoon in South Asia: the role of the air-sea interaction. J Geophys Res 118:1760-1776. doi:10.1002/jgrd.50210

Adler RF, Huffman GJ, Chang A, Ferraro R, Xie P, Janowiak J, Rudolf B, Schneider U, Curtis S, Bolvin D, Gruber A, Susskind J, Arkin $\mathrm{P}$ (2003) The version 2 global precipitation climatology project (GPCP) monthly precipitation analysis (1979-present). J Hydrometeorol 4:1147-1167

Bao Q, Yang J, Liu YM, Wu GX, Wang B (2010) Roles of anomalous Tibetan Plateau warming on the severe 2008 winter storm in central-southern China. Mon Weather Rev 138(6):2375-2384. doi:10.1175/2009MWR2950.1

Barnett TP, Dümenil L, Schlese U, Roeckner E, Latif M (1989) The effect of Eurasian snow cover on regional and global climate variations. J Atmos Sci 46(5):661-685

Boos WR, Kuang ZM (2010) Dominant control of the South Asian monsoon by orographic insulation versus plateau heating. Nature 463(7278):218-223. doi:10.1038/nature08707

Boos WR, Hurley JV (2013) Thermodynamic bias in the multimodel mean boreal summer monsoon. J Clim 26:2279-2287

Dee DP et al (2011) The ERA-Interim re-analysis: configuration and performance of the data assimilation system. Q J R Meteorol Soc 137:553-597. doi:10.1002/qj.828

Duan AM, Wu GX (2005) Role of the Tibetan Plateau thermal forcing in the summer climate patterns over subtropical Asia. Clim Dyn 24:793-807. doi:10.1007/s00382-004-0488-8

Duan AM, Xiao ZX (2015) Does the climate warming hiatus exist over the Tibetan Plateau? Sci Rep 5:13711. doi:10.1038/srep13711

Duan AM, Wu GX, Liang XY (2008) Influence of the Tibetan Plateau on the summer climate patterns over Asia in the IAP/LASG SAMIL model. Adv Atmos Sci 25(4):518-528. doi:10.1007/ s00376-008-0518-2

Duan AM, Sun RZ, He JH (2017) Impact of surface sensible heating over the Tibetan Plateau on the western Pacific subtropical high: a land-air-sea interaction perspective. Adv Atmos Sci 34:157-168

Flohn H (1957) Large-scale aspects of the "summer monsoon" in South and East Asia. J Meteorol Soc Jpn 75:180-186

Hahn DG, Manabe S (1975) The role of mountains in the south Asian monsoon circulation. J Atmos Sci 32(8):1515-1541

Hansen J, Ruedy R, Sato M, Lo K (2010) Global surface temperature change. Rev Geophys 48:RG4004. doi:10.1029/2010RG000345

He S, Yang S, Li Z (2017) Influence of latent heating over the Asian and western Pacific monsoon region on Sahel summer rainfall. Sci Rep 7. doi:10.1038/s41598-017-07971-6

Jiang XW, Ting MF (2017) A dipole pattern of summertime rainfall across the Indian subcontinent and the Tibetan Plateau. J Clim. doi:10.1175/JCLI-D-16-0914.1
Jiang XW, Li YQ, Yang S, Yang K, Chen JW (2016) Interannual variation of summer atmospheric heat source over the Tibetan Plateau and the role of convection around the western Maritime Continent. J Clim 29:121-138. doi:10.1175/JCLI-D-15-0181.1

Kitoh A (2004) Effects of mountain uplift on East Asian summer climate investigated by a coupled atmosphere-ocean GCM. J Clim 17(4):783-802

Liu YM, Wu GX, Liu H, Liu P (2001) Condensation heating of the Asian summer monsoon and the subtropical anticyclone in the Eastern Hemisphere. Clim Dyn 17:327-338

Liu YM, Bao Q, Duan AM, Qian ZA, Wu GX (2007) Recent progress in the impact of the Tibetan Plateau on climate in China. Adv Atmos Sci 24(6):1060-1076

Liu YM, Wu GX, Hong JL, Dong BW, Duan AM, Bao Q, Zhou LJ (2012) Revisiting Asian monsoon formation and change associated with Tibetan Plateau forcing: II. Change. Clim Dyn 39(5):1183-1195. doi:10.1007/s00382-012-1335-y

Liu YM, Wang ZQ, Zhou HF, Wu GX (2017) Two types of summertime heating over Asian large-scale orography and excitation of potential-vorticity forcing II. Sensible heating over Tibetan-Iranian Plateau. Sci China Earth Sci 60(4):733-744. doi:10.1007/ s11430-016-9016-3

Neale RB, Richter J, Park S, Lauritzen PH, Vavrus SJ, Rasch PJ, Zhang M (2013) The mean climate of the community atmosphere model (CAM4) in forced SST and fully coupled experiments. J Clim 26:5150-5168

Rajagopalan B, Molnar P (2013) Signatures of Tibetan Plateau heating on Indian summer monsoon rainfall variability. J Geophys Res 118:1-9. doi:10.1002/jgrd.50124

Rodwell MJ, Hoskins BJ (1996) Monsoon and the dynamics of deserts. Q J R Meteorol Soc 122:1385-1404

Rodwell MJ, Hoskins BJ (2001) Subtropical anticyclones and summer monsoons. J Clim 14:3192-3211

Si D, Ding Y (2013) Decadal change in the correlation pattern between the Tibetan Plateau winter snow and the East Asian summer rainfall during 1979-2011. J Clim 26:7622-7634. doi:10.1175/ JCLI-D-12-00587.1

Su JY, Duan AM, Xu HM (2017) Quantitative analysis of surface warming amplification over the Tibetan Plateau after the late 1990s using surface energy balance equation. Atmos Sci Let 18:112-117. doi:10.1002/asl.732

Wang B, Bao Q, Hoskins B, Wu GX, Liu YM (2008) Tibetan Plateau warming and precipitation changes in East Asia. Geophys Res Lett 35:L14702. doi:10.1029/2008GL034330

Wang ZQ, Duan AM, Wu GX (2014) Time-lagged impact of spring sensible heat over the Tibetan Plateau on the summer rainfall anomaly in East China: case studies using the WRF model. Clim Dyn 42:2885-2898. doi:10.1007/s00382-013-1800-2

Wang ZQ, Duan AM, Li MS, He B (2016) Influences of thermal forcing over the slope/platform of the Tibetan Plateau on Asian summer monsoon: numerical studies with the WRF model. Chin J Geophys 59:474-487

Wu GX, Li WP, Guo H (1997) Sensible heat driven air-pump over the Tibetan Plateau and its impacts on the Asian summer monsoon. In: Ye DZ (ed) Collections on the memory of Zhao Jiuzhang. Science Press, Beijing, pp 116-126

Wu GX, Liu YM, Wang TM, Wan RJ, Liu X, Li WP, Wang ZZ, Zhang Q, Duan AM, Liang XY (2007) The influence of mechanical and thermal forcing by the Tibetan Plateau on Asian climate. J Hydrometeorol 8:770-789

Wu GX, Liu Y, Zhu X, Li W, Ren R, Duan A, Liang X (2009) Multi-scale forcing and the formation of subtropical desert and monsoon. Ann Geophys 27(9):3631-3644. doi:10.5194/ angeo-27-3631-2009 
Wu GX, Liu YM, He B, Bao Q, Duan AM, Jin FF (2012a) Thermal controls on the Asian summer monsoon. Sci Rep 2:404. doi:10.1038/srep00404

Wu ZW, Li JP, Jiang ZH, Ma TT (2012b) Modulation of the Tibetan Plateau snow cover on the ENSO teleconnections: from the East Asian summer monsoon perspective. J Clim 25:2481-2489. doi:10.1175/JCLI-D-11-00135.1

Wu GX, Duan AM, Liu YM, Mao JY, Ren RC, Bao Q, He B, Liu BQ, Hu WT (2014) Tibetan Plateau climate dynamics: recent research progress and outlook. Nat Sci Rev. doi:10.1093/nsr/nwu045

Wu GX, He B, Liu YM, Bao Q (2015) Location and variation of the summertime upper-troposphere temperature maximum over South Asia. Clim Dyn. doi:10.1007/s00382-015-2506-4

Wu GX, Zhuo HF, Wang ZQ, Liu YM (2016) Two types of summertime heating over the Asian large-scale orography and excitation of potential-vorticity forcing I. Over Tibetan Plateau. Sci China Earth Sci 59(10):1996-2008. doi:10.1007/s11430-016-5328-2
Yang S, Lau KM (1998) Influence of sea surface temperature and ground wetness on Asian summer monsoon. J Clim 11:3230-3246

Yang S, Webster PJ, Dong M (1992) Longitudinal heating gradient: another possible factor influencing the intensity of the Asian summer monsoon circulation. Adv Atmos Sci 9(4):397-410

Ye DZ, Wu GX (1998) The role of the heat source of the Tibetan Plateau in the general circulation. Meteorol Atmos Phys 67:181-198

Yeh TC, Lo SW, Chu PC (1957) The wind structure and heat balance in the lower troposphere over Tibetan Plateau and its surrounding. Acta Meteorol Sin 28:108-121

Yeh TC, Wetherald RT, Manabe S (1984) The effect of soil moisture on the short-term climate and hydrology change: a numerical experiment. Mon Weather Rev 112:474-490

Zhao P, Yang S, Wu RG, Wen ZP, Chen JM, Wang HJ (2012) Asian origin of interannual variations of summer climate over the extratropical North Atlantic Ocean. J Clim 25:6594-6609. doi:10.1175/ JCLI-D-11-00617.1 